\title{
The Adequacy of Pre-purchase Due Diligence in Independent Small Business and Franchising
}

\author{
Jenny Buchan \\ UNSW Australia \\ Lorelle Frazer (Corresponding author) \\ Griffith University \\ Brisbane, Australia \\ Telephone: +61 733821179 \\ Email : L.Frazer@griffith.edu.au \\ Scott Weaven \\ Griffith University \\ Binh Tran-Nam \\ UNSW Australia \\ Anthony Grace \\ Griffith University
}

\author{
Classification Codes (JEL): \\ M41 Accounting \\ M13 New Firms/Startups
}

\begin{abstract}
Author Biographies
Jenny Buchan is Associate Professor in the UNSW Australia Business School. She is admitted to practice as a barrister and solicitor in New Zealand, Victoria and New South Wales. Lorelle Frazer is Professor and Director, and Scott Weaven is Professor and Deputy Director, of the Asia-Pacific Centre for Franchising Excellence at Griffith University. Binh Tran-Nam is Professor at UNSW Australia and RMIT Vietnam and is a leading tax academic in Australasia Anthony Grace is a doctoral candidate at Griffith University.
\end{abstract}

\section{Acknowledgement}

This research was funded by CPA Australia under a Global Research Perspectives Program grant.

The views expressed in this paper are those of the authors 


\title{
The Adequacy of Pre-purchase Due Diligence in Independent Small Business and Franchising
}

\begin{abstract}
Summary at a Glance
This research found that prospective franchisees undertake better quality due diligence than prospective independent small business owners when considering the purchase of a franchise or small business. Greater support for potential investors is needed to ensure they understand the need for due diligence, how to perform it effectively and how to use their advisers to best advantage.
\end{abstract}




\begin{abstract}
This research reports an in-depth study of the due diligence activities that prospective independent small business operators and franchisees in Australia undertake prior to purchasing or starting up their business. Although academic literature and industry publications promote undertaking 'proper due diligence', there is a lack of empirical research into the nature of due diligence and its effect on business outcomes. Using a qualitative approach, 60 currently and formerly operating independents and franchisees were personally interviewed, exploring the diversity of approaches to undertaking due diligence prior to entering business.

The research revealed that differences occur in both the type and amount of due diligence undertaken by independents and franchisees and highlighted further differences between current and former operators. In general, the due diligence undertaken by participants was relatively unsophisticated with few exceptions of rigor and planning. Where prospective independents and franchisees were entering business for the first time their appreciation of business was naïve. A steep learning curve followed during which they often recognised flaws in their initial research. As a result of this qualitative depth research, we present a set of propositions regarding due diligence and a model for future testing on a large sample.
\end{abstract}

\title{
Key words
}

Due diligence, Expectations, Franchise, Independent small business, Pre-entry 


\section{INTRODUCTION}

Independent small business owners ('independents') and franchisees are assumed to have conducted due diligence effectively before committing to their business purchase. To protect their own financial interest, buyers should have investigated the business that is being bought, taken professional advice where appropriate and made a decision they will continue to be happy about. The ideal buyer does not commit until he or she has done enough due diligence to understand any major risks involved, decided how they will manage those risks, and satisfied themselves that they have what it will take to run the business profitably. Buying an independent small business differs in significant ways from the purchase of a franchise. For an independent business the actual business, its trading environment, employees and its potential are the focus. For a franchise these things are important too, but will also require the franchisee and franchisor to become long term business 'partners' shackled to one another by mutual obligations under the franchise agreement for its duration.

We explored the due diligence conducted by independents compared to that conducted by franchisees in Australia. Wein, on completing the most recent review of the Code, noted that 'an aspiring franchisee's desire to "buy a job” clouds the 'willingness to analyse objectively the commercial terms and risks or to make sure that expectations match the contractual reality' (Wein, 2013). One industry commentator observes that 'much of the marketing of [franchise] systems is the "putting to sleep" of the candidates' risk aversion mechanisms' (Stewart 2015). If the aspiring franchisee is distracted by a need to 'buy a job’ 
and their risk aversion mechanisms have been tranquilized during the 21 day waiting plus cooling off periods prescribed by Australia’s Franchising Code of Conduct (the Code) this may lead to a reduced degree of due diligence. Do buyers of independent businesses who do not have the benefit of the Code conduct their due diligence differently to franchisees?

The research reported in this paper describes a study of 60 former and current independent small business operators and franchisees. The paper is structured as follows. We start with a review of the relevant literature. This is followed by a justification and description of our research design and data collection and analysis process. Next we present the findings and offer our conclusions and recommendations.

\section{LITERATURE REVIEW}

Due diligence is described in the literature as a procedure used to scrutinise a business opportunity before a binding contract is signed (Bing 1996). In essence, due diligence means the process that investors undertake to satisfy themselves that they are getting what they think they are buying and that what they are buying is worth what they are paying. Due diligence involves a two-way process whereby the purchaser must learn as much as possible about the business being purchased but also relies on the seller being forthcoming with relevant information. This is especially the case where the information is difficult or prohibitively expensive to access from public records. At the outset it is sometimes difficult for the purchaser to know which questions to ask and the seller may be reluctant to provide confidential operational and financial information (Gates 1988). In environments where 
lawyers are involved early, parties typically address these concerns by signing confidentiality agreements.

The small business/entrepreneurial literature focuses on three major considerations of business investors carrying out due diligence (prior to purchase): time constraints, cost constraints, and situational factors. First, time constraints on the due diligence phase (in the case of independents, usually imposed by the seller, and in the case of franchising impacted by statute-imposed minimum time frames) can have a significant impact on a buyers’ ability to effectively evaluate the proposal (Crisafio and Schliebs 1989). Time pressures can hinder the collection of accurate information concerning the target business. Lack of time can also hinder the deeper exploration of any troubling discovery that should merit further investigation. Second, financial constraints play a critical role in the due diligence phase. According to Hearne and Dean (1989), the task of hiring professional advisors to examine every aspect and nuance of the target business can be financially prohibitive. So, also, can the cost of buying information from third parties. Finally, Harvey and Lusch (1995) proposed a framework for understanding the due diligence process as an assessment of situational factors, including intangible and tangible dimensions of the target business. Intangible items include the loyalty of the existing staff, trade secrets, the seller's professional and personal networks, customer loyalty, goodwill, and the competitive position of the business. Tangible items include supplier contracts, location, cash, inventory, patents, plant and equipment. For prospective franchisees a further consideration is the need to investigate the franchisor - as franchisor and franchisee enter an interdependent ongoing relationship of a type that does not exist when an independent 
business is being purchased. Thus, there are many factors for the buyer to consider prior to purchase. These issues contribute to the difficulty in carrying out effective scrutiny of a business opportunity.

One important theme within the business/entrepreneurial literature is the link between due diligence and business performance. Reasons for small business failure are numerous, ranging from limited knowledge and management skills (Beresford and Saunders 2005) to macro-economic cyclical downturns (Fredland and Morris 1976). In franchising, the failure of the franchisor can lead to the failure of its solvent franchisees (Buchan et al. 2015). However, an under-studied area in the small business literature is the extent to which independents carried out comprehensive due diligence before acquiring the target business and the connection this has to subsequent success/failure of that business.

Much of the extant literature has focused on existing organisations conducting due diligence when performing mergers or acquisitions (for example, Dionne 1998; Green 1992; Harmon 1992), whereas little attention has been accorded the role of advisors when individuals purchase a small business or franchise. For example, Fletcher (1988) observed that investors differ greatly in their level of financial sophistication, ranging from unsophisticated investors with little education, limited business experience and few resources, to sophisticated investors with vast resources and education from top business schools, with the latter group less likely to seek or listen to financial advice. Furthermore, Dyer and Ross (2007) explored the communication styles of professional business advisors and how this impacts on the relationship with entrepreneurs. Gibb (1997) goes as far as to 
propose that a small to medium enterprise's (SME) ability to survive is a function of its ability to learn from certain stakeholders (e.g., accountants, lawyers, bankers). However, this can be difficult because, according to Zinger et al. (1996), entrepreneurs usually consider themselves to be fiercely independent and a need to ask for advice might damage that perception. On the other hand, some argue that advisers (particularly accountants) play a vital role in the emotional wellbeing of investors because of their role as a professional service provider (Carter et al. 2013). Even though accountants play a technical role in serving their clients' needs, such as financial record-keeping (Smith et al. 2000), research suggests the accounting profession's role may extend to community wellbeing as it strives to serve in the public interest (Ciccotosto et al. 2008; Carter et al. 2013). The role of small business advisors may constantly be changing and expanding, yet the role they play in effective due diligence remains important.

Due diligence is considered to be a tool for risk reduction (Fiet 1995; Douglas and Shepherd 2002) because risks multiply when all aspects of a business are not objectively and comprehensively reviewed (Bing 1996). It must be acknowledged, however, that even the idea of 'what is a risk' is not clear. As observed by Carlon et al '[t]here has been little international consensus on what is meant by the terms "risk and "uncertainties" (Carlon et al 2003). The process of carrying out due diligence is inherently subjective and will differ greatly among individuals due to their personal attitudes toward risk. Risk is usually assessed against two benchmark criteria: (1) the magnitude of potential loss, and (2) the chance of an event occurring (Weber and Milliman 1997; SAI Global 2009). Thus the purpose of due diligence is to give investors and their financiers sufficient peace of mind 
(that is, ample knowledge of where risks lie to evaluate and if appropriate reduce them) in order to have confidence to either proceed with the binding contract, and accept the commercial and legal risk, or decline to proceed on the basis proposed. However, the comprehensiveness of the due diligence carried out may differ greatly depending on the financial sophistication and means of the investor: a sophisticated investor is more likely to objectively review a business opportunity than an unsophisticated investor, yet courts hold them to the same due diligence standard (Fletcher 1988). A sophisticated investor in Australia is a person who meets the criteria in s 708(8) Corporations Act 2001 (Cth). For a sophisticated investor the business opportunity will most likely be part of a portfolio of investments. An unsophisticated investor, however, may be investing in one business to the limits of their equity and borrowing capacity.

Just as professional advisers presume a potential buyer will conduct due diligence, so do the courts. When a dispute about a business purchase reaches court, the plaintiff will be subjected to cross-examination about the type and extent of due diligence they conducted pre-purchase. Judges assume the purchaser had the opportunity to conduct due diligence and entered the arrangement sufficiently informed about the risks and consequences of doing so. For example in Fair Work Ombudsman v Hiyi Pty Ltd \& Ors [2016] FCCA 1634 Judge Jones wrote

'... I would expect that the Second and Third Respondents would have undertaken due diligence before entering into the franchise' (para 39). 
To assist with conducting due diligence of a franchised business governments in at least 28 countries $^{1}$ require franchisors to provide franchisees with pre-contract disclosure (Spencer 2010, Zeidman 2016) but, unlike sophisticated investor rules for the sale of securities, national franchise disclosure laws typically do not differentiate between a sophisticated and an unsophisticated buyer. An exception is the province of Ontario ${ }^{2}$ Canada, which exempts franchisors from the need to make disclosure to an investor 'who invests more than a prescribed amount (currently C\$5 million) in the acquisition and operation of the franchise over a prescribed period (currently one year)’ (Floriani et al 2015, 32).

Comprehensive due diligence should increase the probability that significant aspects of the opportunity are not overlooked. It cannot guarantee business success, although it may improve the odds slightly (Bing 1996). It is also recognised by some legal academics that more disclosure is not always better (Atwell 2015). Thus, it is useful to develop robust tools for due diligence that can be used as templates for objective scrutiny. These tools would ensure that both sophisticated and unsophisticated investors are able to make informed decisions prior to committing to buy an independent or franchised small business, thus filling a gap in the existing literature. We start by updating our understanding of the conduct of due diligence by independents and comparing these with franchisees.

\footnotetext{
${ }^{1}$ Albania, Argentina, Australia, Azerbaijan, Belgium, Brazil, Canada (Alberta, British Columbia, Manitoba, New Brunswick, Ontario, Prince Edward Island), China, France, Georgia, Indonesia, Italy, Japan, Latvia, Malaysia, Moldovia, Mongolia, Macau, Romania, South Africa, South Korea, Spain, Sweden, Tunisia, Turkmenistan, United States, Vietnam.

${ }^{2}$ Arthur Wishart Act (Franchise Disclosure) 2000, s 5(7)(g)(i).
} 


\section{RESEARCH DESIGN}

\section{Methodology}

A qualitative methodology was adopted for this research for four reasons. Firstly, the focus of qualitative research is to construct a social reality (Neuman 2013) through the lens of personal observation and experience. Qualitative research enables researchers to examine and interpret how others represent their own social reality (Mertens 2010; Denzin \& Lincoln 2011) thus revealing valuable insights. Secondly, qualitative methods are best suited to research exploring the reasons and background for the phenomena being studied (Carson et al. 2001). Unlike quantitative research, which places emphasis on the measurement and analysis of the underlying relationships among variables, qualitative research focuses on understanding the personal experiences and perspectives of study participants (Silverman 2014). Thirdly, as we were attempting to understand the process undertaken by prospective independents in assessing a business opportunity prior to purchase, the research was exploratory in nature (Yin 2014). Finally, exploratory research was appropriate as the topic of due diligence in independent small business and franchising has received scant attention in the academic literature. Discussion surrounding the importance of due diligence abounds in industry publications and blogs, and its importance is assumed by policy makers, regulators, accountants, lawyers, judges and professional and industry bodies, yet little empirical research has been carried out to test the assertion that due diligence is actually an effective strategy for assessing the risk of a business opportunity. 
Using a realism paradigm (Perry 1998) we studied the perceptions of current and former independents and franchisees about their understanding and approach to undertaking due diligence prior to purchase or start up. Respondents’ perceptions were valuable because they provided a lens through which to investigate the due diligence phenomenon (Healy \& Perry 2000). As we included both currently operating and former small businesses and franchisees in our study we used the emerging findings to shape the questions and themes for subsequent interviews (Newman 2013). Such flexibility was necessary to allow us to be receptive to new factors as they surfaced. We adopted a recursive research process, synthesising existing theory and involving concurrent data collection and analysis (Veal 2005), finally resulting in a set of propositions for future testing.

To ensure that our approach resulted in valid knowledge we applied Silverman’s (2014) framework for evaluating the credibility of qualitative research. The criteria included seeking clarity about the research question and ensuring we used a systematic data collection and record keeping approach. Moreover, we ensured that the sensitivity of the research method was appropriate for the research question. Hence, two members of the research team personally interviewed an initial sample of independents and franchisees, firstly building rapport with them before canvassing sensitive issues surrounding their due diligence, and calibrating questions accordingly. We ensured reliability of the data by using a standardised interview protocol. In addition, we maintained reliability by having all members of the research team interpret the qualitative data. When reporting the results we used examples and included evidence that was representative of the findings, thus avoiding 
as much as possible resorting to anecdotes, or ignoring contradictory data (Silverman 2015).

To improve the validity of the research we employed the constant comparative method of data analysis (Silverman 2015). This approach involved the continuous testing of provisional hypotheses on additional cases. Because of the varying experiences of current and former independents and franchisees we refined and tested emerging propositions as the interviews progressed. Boeije (2002) contends that use of the constant comparative method to compare emerging findings with new data reinforces external validity, providing a strong basis for generalisation of the findings.

\section{DATA COLLECTION \& ANALYSIS}

\section{Data Collection}

We used theoretical sampling to undertake the research as our goal was to develop theoretical concepts that emerged from the experiences of the research participants (Glaser \& Stauss 1967; Patton 2015). Theoretical sampling enabled us to tailor the data collection as theory emerged through an iterative data analysis process.

Interviews were conducted with a sample of 60 current and former independents and franchisees. The sample selection was purposeful and involved the identification and selection of information-rich cases (Patton 2015). Through our existing networks and a process of snowball sampling (Palinkas et al. 2013), we identified potential participants who had experienced the purchase or start-up of a small business or franchise and who 
could thus provide insightful information about the phenomenon of interest. The use of snowballing is recommended when there is a specific population with relevant knowledge or experience (Neuman 2013). We were careful to select the first few participants who met our criteria and who were able to recommend others with relevant experience (Carson et al. 2001). Hence, sample selection was also based on convenience and was emergent (Palinkas et al. 2013).

Based on Gates’ (1988: 10-11) list of 'basic requests’ when conducting due diligence, on a proposed acquisition, we ensured our interview questions included the following topics: history of the business, production and/or sources of supply, facilities, marketing, financial information, assets (including intangibles), liabilities (including contingencies), economic outlook and competition, and Human Resource (HR) issues such as staffing. Convergence of themes was obtained from the interviews, providing a sufficient depth of data to form tentative propositions about the research issues. Convergent interviewing was used because it is particularly suited to topics that have not been highly researched (Dick 1990) such as ours. This technique uses a cyclical approach of ongoing analysis as the interviews proceed. It is recommended for use when more than one interviewer is involved in order to reach a shared understanding about the themes presenting in the data. As the interviews in this study were shared within the research team the convergent interviewing approach was appropriate. Following each interview we examined areas of agreement and disagreement among the participants and pursued these in subsequent interviews. The process of continuously refining the content of the interviews occurred until we were satisfied that 
convergence of themes was obtained (Rao \& Perry 2003) and no new substantive information would be acquired (Miles et al. 2014).

The interview questions were semi-structured, ensuring that key themes were explored but allowing the possibility of new concepts being raised by interviewees when probed. Two pilot interviews were conducted initially as a means of refining the interview protocol (Perry 1998). Interviews were conducted in March and April 2015 and ranged from 15 to 90 minutes in length, with most lasting about 45 minutes. Where possible, they were conducted in person, but as participants were located throughout Australia, including regional and remote areas, some of the interviews were conducted by telephone. With participants’ permission the interviews were recorded and later transcribed.

The sample comprised 22 independents and 18 franchisees who were currently operating, together with 10 former independents and 10 former franchisees, providing a total of 60 participants as noted in Table 1 . The selection of 40 currently operating business owners and 20 former operators was chosen to ensure a wide range of experiences and opinions were canvassed.

The profile of respondents is provided in Table 2. In brief, the gender breakdown of 62 percent males and 38 percent females roughly reflects the gender distribution in the Australian small business and franchising populations. Sixty eight percent of participants were located in capital cities, 30 percent were from regional locations and 2 percent (one interviewee) were situated in a remote location. A wide representation of industries was 
included in the sample. The average business experience was 7.2 years; and ranged from one month to 22 years. Participants who had started (new) 'greenfield' sites (68 percent) and those purchasing existing businesses (32 percent) were included in the sample. The level of business experience was varied. The sample included participants with no previous business experience (58 percent) as well as those who had previously owned a business (28 percent) and a further 14 percent who had owned more than one business previously. Participants were relatively well educated. Sixty five percent were tertiary qualified and the remaining 35 percent were educated to secondary school level. However, 45 percent of participants had no business education. A proportion of participants (42 percent) had no family history of business ownership. In summary, the sample included a rich diversity in the level of knowledge, background and experience of the research participants, thus providing a suitable sample for in-depth qualitative analysis. The emergent themes are explained in the following section.

\section{Data Analysis}

To ensure that the data analysis and findings were rigorous we applied a thematic network analysis (Attride-Stirling 2001) to the research. This process ensures that the data analysis is both methodical and comprehensive. Firstly, the 60 interviews were analysed manually by coding words and phrases according to prior theoretical notions or new concepts raised during the interview process (Carson et al. 2001). Next, the data were analysed using NVivo qualitative data analysis software to assist in the management of the large volume of data and to facilitate the development of theoretical concepts (Gibbs 2002). A coding framework was adopted to create a general database of the recurrent themes which was then 
categorised into a further two levels of organising and global themes. These themes are discussed below.

Theme 1: Approach to due diligence. The research revealed varying levels of knowledge about due diligence among the different participant cohorts. The majority of interviewees were familiar with the concept of due diligence but several misunderstood the term. Those who had a background in business or who had undertaken business education were more likely to be familiar with the notion of due diligence. In general, it appeared that franchisees understood the process of due diligence but their commitment was fairly cursory, possibly relying on the franchisor and the mandatory franchise disclosure document as substitutes for their taking personal responsibility. For example, these comments indicated the participants had an appreciation of the role of due diligence:

Do a bit of research and have a look at the market potential and what you're getting involved in. (Current independent, retail);

... really doing your homework before you open the doors (Former independent, education);

... making sure that what you think you are buying is what you are buying (Current franchisee, fast food); and 
... doing research before you make a decision (Former franchisee, business services).

However, some participants were unfamiliar with or misunderstood the concept of due diligence as illustrated by these responses:

To be honest, I don't know [what the term means] (Current independent, personal services); and

An ethical responsibility as a business owner and a personal community member (Current independent, café).

Table 3 describes the types of due diligence undertaken by both independents and franchisees. The most common activity was to use the services of an accountant. However, the data revealed that most participants tended to use their current accountant rather than seek one with relevant small business or franchising expertise. For example:

I used the family bookkeeper to do my books and I should have used someone who really understood the retail trade. (Former independent, non-food retail).

This is consistent with previous research that found that small business owners are loyal towards their external accountants and tend to use them as their only source of advice, rather than seeking an accountant with specific expertise (Sarens et al. 2015).Independents 
were less likely to use lawyers to assist with due diligence than franchisees were. Franchisees are directed to consult professional advisors by the Code, which prescribes:

10 (2) Before a franchise agreement is entered into, the franchisor must have received from the prospective franchisee:

(a) signed statements, that the prospective franchisee has been given advice about the proposed franchise agreement or franchised business, by:

(i) an independent legal adviser; or

(ii) an independent business adviser; or

(iii) an independent accountant; or

(b) for each kind of statement not received under paragraph (a), asigned statement by the prospective franchisee that the prospective franchisee:

(i) has been given that kind of advice about the proposed franchise agreement or franchised business; or

(ii) has been told that that kind of advice should be sought

but has decided not to seek it. (Schedule 1, Part 2, Division 2, Clause 10)

Given that franchisees enter a long-term, mutual, legal commitment with their franchisor, their use of lawyers is not surprising. Of those franchisees who did consult lawyers, some were not aware of the degree to which changes to a franchise agreement can sometimes be negotiated with a franchisor. For example an experienced fast-food franchisee commented:

There were a number of things that my solicitor recommended that were showstoppers and they decided to fix the showstoppers. I was prepared to negotiate some things and others they [the franchisor] said "no way". We met in the middle in a lot of areas. A lot of prospective franchisees do not realise how much power they actually have as franchisors want good operators. 
It should also be noted that earlier research on small business buyers including franchisees found that 'just under half of the interviewees indicated that they had ignored or overridden the advice provided by external advisors in their quest to become self-employed’ (Frazer, Weaven, Grace 2012).

Another area of difference between the two business models was in relation to conducting market research, where we found considerably fewer franchisees than independents took the initiative. This less than robust approach is not unexpected because a perceived benefit of entering franchising is access to an established brand, whereas independents need to analyse their market opportunities without the assistance of a franchisor.

The type of due diligence undertaken by prospective business investors provides insight into the extent and breadth of activities selected. However, to better gauge the quality of due diligence undertaken it is relevant to observe the amount of time spent on the process. We asked participants to recall the time span over which the due diligence process occurred (rather than to estimate the amount of time on task which would be difficult to recall). As shown in Table 4, the average time spent on due diligence was 16.1 weeks across all participants. However, the data reveals that currently operating independents and franchisees were more measured in their research taking 16.7 weeks and 21.7 weeks respectively. Vast differences in the amount of time taken by former operators were apparent with former independents taking 14 weeks and former franchisees spending just 5.4 weeks on due diligence. Indeed six people (five of whom were independents) indicated their due diligence took no time at all. 
A former franchisee involved in business services recalled minimal time spent on due diligence:

We basically had a meeting with them [the franchisor] for about two hours. Then they sent us all the paperwork which we went over and then we gave it to our solicitor to have a look through ... it would have only been a matter of days.

In contrast, a more thorough approach was taken by a current fast-food franchisee:

[The due diligence] took probably 12 months from enquiry, looking at figures and going through the different stages, looking at documents, going to see the solicitor and accountant, reviewing business plans and so forth.

Similar differences were found in relation to the cost of due diligence (that is, the amount that prospective investors paid in order to complete their due diligence). The average cost of due diligence across the sample was $A \$ 3,214$. Currently operating independent operators spent an average of $A \$ 2,808$ on due diligence compared with $A \$ 5,003$ by franchisees. In contrast, former independent operators spent an average of $\mathrm{A} \$ 2,422$ compared with A $\$ 1,520$ incurred by former franchisees. Ten independents and six franchisees reported that they spent nothing at all on due diligence, highlighting the fact that some prospective 
business owners are reluctant to invest money on due diligence. For instance a currently operating retail franchisee noted:

It cost me $\$ 240,000$ to buy the franchise ... most of this was for stock. There was no way that I could afford to spend money on a lawyer or accountant. I was totally stretched.

The results from these broad ranging interviews suggest that independents and franchisees may differ in the type and amount of due diligence they undertake prior to starting up or purchasing an existing business. These differences may be due to technical constraints on the type of skills and capabilities required to perform the appropriate due diligence investigations. There are also informational constraints. Accessing relevant information to perform due diligence can be difficult and expensive. It can be impossible; for example the 7-Eleven master franchisee for Australia is an exempt proprietary company under s69 Corporations Act 2001 and thus exempt from filing ASIC returns since 1994. Buyers should expect to be given unfettered access, which may necessitate their signing confidentiality agreements at an early stage of negotiations. Sellers often attempt to impose limitations for commercial, legal and even personal reasons. Independents and franchisees need, and have the right to different information in order to effectively carry out their due diligence.

The variety of due diligence activities reported by participants also highlights the degree of formality associated with conducting thorough due diligence. Entrepreneurs differ greatly 
in their approach to conducting due diligence. Some admitted to doing no due diligence at all ('you have a good idea ... and you just start'), others had a very informal attitude to the task (such as talking to family or friends) and the rest were more systematic in their approach. Often, a great deal of trust was placed in other people such as the accountant or lawyer, the previous business owner or the franchisor).

In summary, the due diligence activities undertaken by independents and franchisees are likely to be different. Hence, we propose:

Proposition 1: There is a difference in the type of due diligence undertaken by independents and franchisees.

Theme 2: Financial performance. We asked participants to compare their initial expectations about business performance to their actual performance over time. Most interviewees did not expect to perform well initially but expected to do so as time progressed. For instance:

I was not expecting losses but our initial builder went bankrupt. We made an operational profit despite that. We traded profitably in the first 12 months so my expectations were met. (Current independent, café)

However, some people discovered that financial success took longer to achieve than anticipated: 
I thought I'd have a lot more free time and make a lot more money. Both were wrong ... My expectations were that I'd be making 100k a year and driving a Maserati. In reality I drove a Hyundai for seven years! (Current independent, media)

Others indicated that they had to be satisfied earning less than their previous employment:

I was paying myself the absolute minimum. We often had weeks when there was just enough money for wages and who would be the first one that didn't get paid? It was me! I had to pay staff before paying myself. (Current independent, personal services)

The motivations for entering small business can be characterised as emotional as well as pragmatic or financial. If the motivation for buying a business is purely to maximise return on investment and the buyer is aware of the role of due diligence, it is highly likely that a thorough investigation will be undertaken. In contrast, the buyer with no awareness of due diligence who seeks a business purely for lifestyle reasons, may not accord high priority to due diligence. In other circumstances, a buyer may be directed to undertake due diligence to comply with legislation, or by a financier or other third-party. Emotional attachment to the idea of the business venture was a strong driver for the majority of owners. Most considered only one business opportunity and a minority considered two different possibilities. It is possible that people's minds were made up from the beginning, and that 
their emotional attachment then skewed their due diligence which became a subjective, rather than an objective, exercise. Wein recognised this in agreeing that the risk statement that is now required to be provided to franchisees with the disclosure document 'should be provided to franchisees in advance of formal disclosure to ensure the message is conveyed prior to the franchisee becoming emotionally invested in the particular franchise opportunity is persuasive' (Wein, 2014, 40). We uncovered only two cases in which participants were able to demonstrate 'dispassionate interest' as most were already somewhat emotionally committed to the venture prior to commencing the due diligence exercise. It is a given that a major requisite for effective due diligence is the ability to keep an open mind, to dispassionately question information that is presented and to pursue disclosure of information that appears to be missing. Some participants actively chose to turn a blind eye to information that was uncovered or that would have been relatively easy to scrutinise in more depth. Hence, we suggest:

Proposition 2: Due diligence positively affects the performance of independents and franchisees.

Theme 3. Satisfaction. As a final reflection in the interviews we asked participants to rate (on a scale of 1 to 10 ) their current level of overall satisfaction with the business (for current business owners) or their level of satisfaction at the time they exited the business (for former business owners). Results across the samples are provided in Table 5. Both currently operating independents and franchisees were reasonably satisfied, with levels of 
satisfaction of 8.2/10 and 7.9/10 respectively. Former independents on 6.3 and former franchisees on 6.4 were somewhat less satisfied with their former business.

If their rating was below 10 we also asked participants to indicate what it would take to improve their level of satisfaction. Former business owners rated their levels of satisfaction lower than those currently in operation. An explanation for exiting was that business owners sought improvements in their life styles. For instance:

Things like travel are non-existent because you are chained to the business. (Former independent, hospitality)

One independent business owner operating in media rated his level of satisfaction (out of 10) as ' 11 ', crediting his personal achievement:

Because I've done things in the last seven years that most people will never do in their entire life time.

Franchisees tended to request more support and understanding from their franchisors as a means of improving overall satisfaction. For instance:

The head office support has not been as much as I would have liked. (Current franchisee, hospitality). 
Similarly, satisfaction would be higher:

If the franchisor started doing their role, which is investing in the brand and the brand profile in the market - basically getting their feet in the stores. (Current franchisee, café),

and:

If the franchisor was a little bit more understanding of the challenges involved in our operations. (Current franchisee, finance)

Satisfaction with the business may be driven by variables such as lifestyle, financial rewards or personal achievement. However, the greater the level of preparation undertaken prior to entering the business, the less likely there will be unwelcome surprises once the business commences. Hence, we propose that:

Proposition 3: Due diligence impacts on the satisfaction level experienced by independents and franchisees.

Theme 4. Expectations vs reality. We asked participants to relate their initial expectations about the business across three areas - lifestyle, financial performance and relationships and to reflect on whether these expectations had been met. In the case of independents we focused their relationships with other contractual parties such as key suppliers and 
landlords, whereas franchisees were asked to consider the franchisor-franchisee relationship.

In terms of lifestyle, most people had realistic expectations about how hard they would need to work, particularly in the first couple of years of the business. They were prepared to do this to become successful. Some were seeking more flexibility than they were able to achieve but, on balance, they were generally satisfied with their level of autonomy.

Some participants related that they had to work very hard in the initial stages of the business but that eventually they reaped rewards. For instance:

I was often getting to bed at 1 o'clock in the morning, doing 5 or 6 appointments a day, driving to see people 6 days and sometimes 7 days a week. It's a different story for me now. I don't even have to work. My family is in the business and I have staff. I just come in to make decisions and to ensure that people are going in the right direction. (Current franchisee, finance).

Others were not expecting to work as hard as became necessary. For example:

I was happy to work a normal 40-hour week and then employ people to do weekends and evenings ... I was supposed to employ two staff. It quickly became apparent that the cost could not be afforded. It was assumed that you and your partner would be those two staff! (Former franchisee, fast food) 
Sometimes there was a trade-off between the lifestyle that self-employment provided and financial rewards:

I expected that the amount of money that I would earn would be less than when I was employed, but I also expected that I would be working less hours, more flexible hours. So basically I was expecting my income to go down but my free time to go up ... and that's how it worked out. I'm not trying to make a lot of money out of it ... if the work isn't there I have other things in life that I enjoy. (Current independent, construction)

The need to work very hard in the initial phase of the business sometimes had a detrimental effect on people's family and social networks:

For the first 18 months I absolutely worked my butt off. I sacrificed my social and family life. (Former franchisee, education)

Many participants did not set high expectations regarding financial performance. Often they continued to work in paid employment until the business became viable:

When I first started I wasn't looking to make a fortune because I was prepared to still work in my other job. It was just some extra money but it did end up making me a decent wage. I was a single mum with three kids. It did what I 
needed it to do - it paid for my mortgage and all that sort of stuff. I didn't expect it to be as good as it was in the end. (Former franchisee, recreation)

Similarly, in terms of expectations surrounding franchising relationships or relationships with suppliers, most people were not disappointed:

I was not expecting a lot in terms of ongoing handholding. It was just more support and having a relationship with other franchisees and vendors ... I'm pretty happy with the franchisor. (Current franchisee, business services)

At the beginning, we didn't have the funds to pay (suppliers) and we owed them a lot of money. So I had to have really strong relationships with them for them to trust us and to believe in us and to stick with us. And then we became a good payer. For our regular suppliers we have very good relationships. (Current independent, personal services)

Former independents and franchisees tended to relate negative experiences concerning their business relationships:

I expected more jobs to come from [the franchisor] actually. That was not the case. They gave us some but not many. They expected us to do more marketing. (Former franchisee, business services) 
Some franchisees commented that they rarely interact with the franchisor but they prefer to be independent anyway. For instance:

In any franchise business if you don't hear or see them it's a good thing. (Current franchisee, retail)

Table 6 compares the proportion of participants in each business model who indicated that their initial expectations about the business were met.

Whilst the fairly conservative expectations of participants in this study were generally met, some surprises were experienced. Hence, we propose that greater attention to due diligence will align expectations with outcomes/ex post experience:

Proposition 4: Due diligence undertaken accords with the expectations experienced by independents and franchisees.

\section{CONCLUSIONS AND FUTURE RESEARCH}

In many aspects franchising can be seen as a case study for the wider sector within which businesses generally operate, be this the sector or the economy. Franchising, however, is often studied in isolation. Franchisees are seldom compared with independent small business operators. A rare exception to this is Welsh et al. (2011). Our research has provided a departure from the franchise research norm, and provides valuable insights 
about the degree and amount of preparation undertaken before embarking on a business venture.

The research confirmed that the motivations for entering small business are multifaceted and include emotional as well as pragmatic and financial reasons. This finding has important implications for buyers and sellers of small businesses, particularly franchises. In Australia, for instance, the Code requires the franchisor to provide a franchise Disclosure Document at least 14 days before entering into a franchise agreement (or at the time of making a non-refundable payment in relation to the franchise). However, our research indicates that at this stage of the negotiations the prospective franchisee may already be emotionally committed to the purchase and may have difficulty in remaining detached from the decision, and thus not responsive to any adverse findings their due diligence may reveal. Similarly, given the amount of time that it takes to conduct thorough due diligence on both the business and the franchisor, the 14 day period from issue of the Disclosure Document to committing to the franchise allows insufficient time for the prospective franchisee to complete all or most of the research required. There is a risk that the Disclosure Document may serve to delimit the prospective franchisee's due diligence. There may be significant risk factors hidden beyond the boundaries of the information in the Disclosure Document which, consequently, may not be investigated because even if they have been identified there is not sufficient time remaining to permit a thorough investigation. Hence, prospective franchisees need to be encouraged to conduct much of their due diligence well before receipt of the Disclosure Document, or to negotiate with the franchisor for a longer period than 14 days in which to conclude due diligence 
Independents do not have a similar legislative framework surrounding their business investment and therefore are not routinely exposed to information urging them to undertake due diligence prior to starting up or purchasing a small business. This may explain why more independents (than franchisees) in our sample did not fully understand the concept of due diligence in relation to making their business investment. When removed from the business environment the term 'due diligence' may confound people who have not been exposed to it. Whilst participants in the research were well educated, many had not specialised in business in their studies. These people, in particular, may be disadvantaged when preparing to enter a small business. Although they may possess certain industry skills or have particular expertise or talent, they may not have developed a high degree of business acumen. Operating a business is a skill in itself and entrepreneurs need to develop this skill in order to succeed. In brief, as there are many roles involved in becoming a successful business owner, entrepreneurs need to be able to delineate between working in the business (skill) and working on the business (acumen).

Overall, the main issue that the research has raised is the general level of naïvety associated with small business ownership, particularly for the first business venture undertaken. Under such circumstances, franchisees should be at an advantage because of the legislative environment and the structure, support and training provided by the franchisor enabling inexperienced operators to become self-employed. Independents, on the other hand, do not have easy access to support once they are operating their business. It is possible for them to outsource professional advice and mentoring but if they are not aware of what due diligence 
entails, independents are less likely to be as thorough in their preparations. In conclusion, both independents and franchisees need to be better educated about what effective due diligence entails, how it should be conducted and how to use advisers appropriately in order to be more fully prepared to enter small business.

The findings of this research also suggest that accountants are not fully utilised by prospective business purchasers to provide relevant financial advice which may reduce the risk of entering an independent small business or franchise. Whereas prospective franchisees seem better prepared than independents and have greater access to information about the proposed investment, both types of prospective purchasers could be more proactive and take greater care in the conduct of their due diligence. Seeking the advice of accountants with specific expertise in small business and/or franchising would be preferable to using an accountant who is merely selected for convenience. Moreover, prior research has shown that traditional methods of valuing family firms may be deficient as they fail to acknowledge the impact of non-financial information on the value of the firm (Hasso \& Duncan 2013). Many prospective franchisees and independents purchase existing businesses which would fall into the 'family firm' category, thus adding to the complexity and difficulty of conducting thorough and accurate due diligence.

The current research has set the scene for a future quantitative study into the due diligence conducted by independents and franchisees. Future research will explore the four propositions developed in this paper with the intention of formulating guidelines for effective pre-purchase due diligence. 


\section{REFERENCES}

Attride-Stirling, J. 2001, ‘Thematic Networks: An Analytic Tool for Qualitative Research’, Qualitative Research, 1, 3: 385-405.

Atwell, C. 2015, 'The Franchisee as a Consumer: Determining the Optimal Duration of Pre-Contractual Disclosure', Journal of Consumer Policy, 38, 4, December: 457489.

Beresford, R. and Saunders, M. N. K. 2005,' Professionalization of the Business Start-up Process', Strategic Change, 14, 6: 337-47.

Bing, G. 1996, Due Diligence Techniques and Analysis: Critical Questions for Business Decisions, Greenwood Publishing Group, Westport CT.

Boeije, J. 2002, 'A Purposeful Approach to the Constant Comparative Method in the Analysis of Qualitative Interviews', Quality \& Quantity, 36, 4, November: 391-409.

Buchan, J., Frazer, L., Qu Z.C., and Nicholls, R. 2015, ‘Franchisor Insolvency in Australia: Profiles, Factors and Impacts', Journal of Marketing Channels, 22, 4: 311-332.

Carlon, S., Loftus, J, and Miller, M. 2003, The Challenge of Risk Reporting: Regulatory and Corporate Responses. Australian Accounting Review, 13(3), 36-51.

Carson, D., Gilmore, A., Perry, C. and Gronhaug, K. 2001, Qualitative Marketing Research, Sage, London.

Carter, A. J., Burritt, R. L., \& Pisaniello, J. D. (2013). Accountants as Emotional Wellbeing Counsellors in Rural Areas. Australian Accounting Review, 23(2), 151-162.

Ciccotosto, S., Nandan, R., \& Smorfitt, D. B. (2008). Issues facing small accounting practices in regional North Queensland: An exploratory study. Australian Accounting Review, 18(4), 324-333. 
Competition and Consumer (Industry Codes—Franchising) Regulation 2014, Select Legislative Instrument No. 168, 2014 (Franchising Code of Conduct, 'the Code').

Crisafio, A., and Schliebs, C. 1989, 'Working in Concert', Pennsylvania CPA Journal, Winter: 23-25.

Denzin, N. K., and Lincoln, Y. S. (Eds.) 2011, The SAGE Handbook of Qualitative Research, 4th Edition, Sage, London, UK.

Dick, R. 1990, Convergent Interviewing, Interchange, Brisbane.

Dionne, J. 1988, 'The art of Acquisitions’, Journal of Business Strategy, NovemberDecember: 13-17.

Douglas, E. J. and Shepherd, D. 2002, ‘Exploring Investor Readiness: Assessments by Entrepreneurs and Investors in Australia', Venture Capital: An international journal of entrepreneurial finance, 4, 3: 219-236.

Dyer, L. M. and Ross, C. A. 2007, 'Advising the Small Business Client', International Small Business Journal, 25, 2: 130-151.

Sarens, G., Everaert, P., Verplancke, F. and De Beelde, I. 2015, ‘Diversification of External Accountants Serving Small and Medium-sized Enterprises: Evidence from Belgium’ Australian Accounting Review, 73, 25, 2: 155-174.

Fiet, J. O. 1995,' Reliance upon Informants in the Venture Capital Industry', Journal of Business Venturing, 10, 3: 195-223.

Fletcher, C. E. 1988, 'Sophisticated Investors Under the Federal Securities Law’, Duke Law Journal: 1081-1154.

Floriani, B., Liebman, M., and Carnevale, M. in PF Zeidman (ed) 2016, Getting the Deal Through: Franchise, CANADA, 32 
http://www.franchise.org/sites/default/files/uploaded_documents/F2016\%20Canada .pdf last accessed 4 August 2016.

Frazer, L., Weaven, Grace, D. 2012, Survival of the fittest: The performance of franchised versus independent small business during economic uncertainty and recovery

Fredland, E. J. and Morris, C. E. 1976, ‘A Cross Section Analysis of Small Business Failure’, American Journal of Small Business, 1, July: 7-18.

Gates, C. 1988, 'Get the Most from your Acquisition', Journal of Business Strategy, November/December: 8-11.

Gibb, A. 1997, ‘Small Firms’ Training and Competitiveness: Building Upon the Small Business as a Learning Organisation', International Small Business Journal, 15, 3: $13-29$.

Gibbs, G. 2002, Qualitative Data Analysis: Explorations with NVivo, Open University Press, Buckingham, UK.

Green, J. 1992, 'Structuring an Acquisition Strategy', Small Business Reports, December: 50-59.

Glaser, B. and Strauss, A. 1967, The Discovery of Grounded Theory: Strategies for Qualitative Research, Aldine Pub. Co., New York.

Harmon, E. 1992, '16 Fatal Flaws that can Undermine an Acquisition, Mergers and Acquisitions, January-February: 36-38.

Hasso, T. and Duncan, K. 2013, 'Valuation of Family Firms: The Limitations of Accounting Information', Australian Accounting Review, 65, 23, 2: 135-150.

Harvey, M. G. and Lusch, R. F. 1995, 'Expanding the Nature and Scope of Due Diligence', Journal of Business Venturing, 10, 1: 5-21. 
Healy, M. and Perry, C. 2000, ‘Comprehensive Criteria to Judge Valildity and Reliability of Qualitative Research within the Realism Paradigm', Qualitative Market Research: An International Journal, 3, 3: 118-126.

Hearne, J. and Dean, D. 1989, 'The Preacquisition Search for Environmental Risks', Mergers and Acquisitions, January-February: 33-39.

Mertens, D. 2010, Research and evaluation in education and psychology: integrating diversity with quantitative, qualitative and mixed methods, 3rd Edition, Sage, Thousand Oaks, CA.

Miles, M., Huberman, M. and Saldana, J. 2014, Qualitative Data Analysis: A Methods Sourcebook, Sage, Thousand Oaks, CA.

Neuman, W. 2013, Social research methods : qualitative and quantitative approaches. Harlow, $7^{\text {th }}$ Edition, Essex, Pearson Education, New York.

Palinkas, L., Wisdom, J., Green, C. and Hoagwood, K. 2013, 'Purposeful Sampling for Qualitative Data Collection and Analysis in Mixed Method Implementation Research', Administration and Policy in Mental Health and Mental Health Services Research, November.

Patton, M. 2015, Qualitative Research and Evaluation Methods: Integrating Theory and Practice, Sage, Thousand Oaks, CA.

Perry, C. 1998, 'Processes of a Case Study Methodology for Postgraduate Research in Marketing', European Journal of Marketing, 32, 9/10: 785-802.

Rao, S. and Perry, C. 2003, 'Convergent Interviewing to Build a Theory in Underresearched Areas: Principles and an Example Investigation of Internet usage in 
Inter-Firm Relationships’, Qualitative Market Research: An International Journal, 6, 4: 236-247.

SAI Global 2009, S/NZS ISO 31000:2009 Risk management - Principles and guidelines.

Silverman, D. 2014, Doing Qualitative Research, $4^{\text {th }}$ Edition, Sage, London.

Silverman, D. 2015, Interpreting Qualitative Data, 5th Edition, Sage, London.

Smith, M., \& Briggs, S. (2000). Accounting stereotypes. In Smith, M and Gurd, B (eds) Accounting, Organisations and Society, Prentice Hall, Frenchs Forest, 1-25.

Spencer, E. C. 2010, The Regulation of Franchising in the New Global Economy, Edward Elgar, London.

Stewart, L. 2015, The Conversation, 11 September, Blog comment, available at https://theconversation.com/if-theres-so-little-profit-why-do-people-buy-7-elevenfranchises-47033\#comment_783376 last accessed 8 February 2016.

Veal, A. 2005, Business Research Methods: A Managerial Approach, Pearson, Frenchs Forest.

Wein, A. 2013, Review of the Franchising Code of Conduct, Report to: The Hon Gary Gray AO MP, Minister for Small Business and The Hon Bernie Ripoll MP, Parliamentary Secretary for Small Business.

Weber, E. U. and Milliman, R. A. 1997, 'Perceived Risk Attitudes: Relating Risk Perception to Risky Choice’, Management Science, 43, 2: 123-144.

Welsh, D. H. B., Desplaces, D. E. and Davis, A.E. 2011, 'A Comparison of Retail Franchises, Independent Businesses, and Purchased Existing Independent Business Startups: Lessons from the Kauffman Firm Survey’, Journal of Marketing Channels,18, 1: 3-18. 
Yin, R.K. 2014, Case Study Research: Design and Methods, Sage, Thousand Oaks, CA. Zeidman P F.(ed), 2016, Getting the Deal Through: Franchise.

Zinger, J., Blanco, H., Zanibbi, L. and Mount, J. 1996, ‘An Empirical Study of the Small Business Support Network’, Canadian Journal of Administrative Sciences, 13, 4: 347-57. 
Table 1 Composition of sample

\begin{tabular}{lccc|} 
Sample & Independents & Franchisees & Total \\
\hline Currently operating & $22(37 \%)$ & $18(30 \%)$ & $40(67 \%)$ \\
Formerly operating & $10(16.5 \%)$ & $10(16.5 \%)$ & $20(33 \%)$ \\
Total & $\mathbf{3 2 ( 5 3 . 5 \% )}$ & $\mathbf{2 8 ( 4 6 . 5 \% )}$ & $\mathbf{6 0}(\mathbf{1 0 0 \% )}$
\end{tabular}




\section{Table 2 Respondent Profile}

$(n=60)$

\begin{tabular}{|c|c|c|c|c|c|}
\hline \multirow[t]{2}{*}{ Characteristics } & \multicolumn{3}{|c|}{$\begin{array}{l}\text { Currently } \\
\text { Operating }\end{array}$} & \multicolumn{2}{|c|}{ Formerly Operating } \\
\hline & $\begin{array}{r}\text { Total } \\
\text { Sample } \\
(\%)\end{array}$ & $\begin{array}{r}\text { Independent } \\
(\%)\end{array}$ & $\begin{array}{r}\text { Franchisee } \\
(\%)\end{array}$ & $\begin{array}{r}\text { Independent } \\
(\%)\end{array}$ & $\begin{array}{r}\text { Franchisee } \\
(\%)\end{array}$ \\
\hline \multicolumn{6}{|l|}{ Gender (\%) } \\
\hline Male & 62 & 64 & 83 & 50 & 30 \\
\hline Female & 38 & 36 & 17 & 50 & 70 \\
\hline \multicolumn{6}{|l|}{ Age (\%) } \\
\hline Under 30 years & 7 & 45 & 11 & 20 & 0 \\
\hline 31 to 45 years & 33 & 41 & 22 & 30 & 30 \\
\hline 46 to 60 years & 48 & 14 & 50 & 50 & 60 \\
\hline Over 60 years & 12 & 0 & 17 & 0 & 10 \\
\hline
\end{tabular}

\section{Birthplace (\%)}

Born in Australia

Born overseas
77

23
73

27
83

17
70

30

80

20

\section{Location (\%)}

Capital city

Regional town or city

Remote locality

68

30

2

55
45
0

72
22
6

90

70

10

30

0

\section{Industry (\%)}

Fast food / Retail food

15

Cafes / Restaurants

Administration/ support

Retail (non-food)

Education / training

Personal services

Media / telecommunications

Arts / recreation

Finance / insurance

Construction

Manufacturing

Rental / hire / real estate

Other industry

$\begin{array}{rrrrr}15 & 4 & 22 & 10 & 30 \\ 15 & 14 & 28 & 10 & 0 \\ 13 & 14 & 6 & 10 & 30 \\ 12 & 18 & 11 & 10 & 0 \\ 10 & 0 & 11 & 10 & 30 \\ 8 & 14 & 0 & 10 & 10 \\ 5 & 9 & 0 & 10 & 0 \\ 3 & 9 & 0 & 0 & 0 \\ 3 & 0 & 11 & 0 & 0 \\ 3 & 5 & 0 & 10 & 0 \\ 3 & 0 & 0 & 20 & 0 \\ 2 & 4 & 0 & 0 & 0 \\ 7 & 9 & 11 & 0 & 0\end{array}$


$\begin{array}{llllll}\text { Experience (number of years operating) } & 7.2 \text { yrs } & 6.6 \text { yrs } & 6.8 \text { yrs } & 6.6 \text { yrs } & 9.8 \text { yrs }\end{array}$

Business type (\%)

Started new (greenfield)

68

32

73

50

80

80

Purchased existing business

27

50

20

20

\section{Legal structure (\%)}

Sole Trader

Partnership

32

3

Trust

12

Proprietary Limited Company

53

27

9

9

55

58

28

41

66

70

70

Previously owned a

41

17

20

30

business/franchise

More than one prior

14

18

17

0

10

business/franchise

\section{Highest level of education (\%)}

Secondary school

TAFE

35

12

Undergraduate degree

28

Masters degree

Higher degree

22

3

\section{6}

39

30

30

14

11

10

10

27

28

40

30

23

22

10

20

10

10

\section{Business education (\%)}

Short courses in business

TAFE business course

Undergraduate degree in business

10

13

0

0

10

30

20

0

Masters degree or higher in

business

No specific business education

45

9
18

16

20

5

14

11

30

0

45

54

39

20

60

Family history of business ownership (\%)

No family history

Family history - direct

42

42

32

50

33

70

50

involvement 
Family history - some involvement

N/A

29

N/A

Note: Percentages rounded to whole numbers for ease of comprehension 
Table 3 Due Diligence undertaken

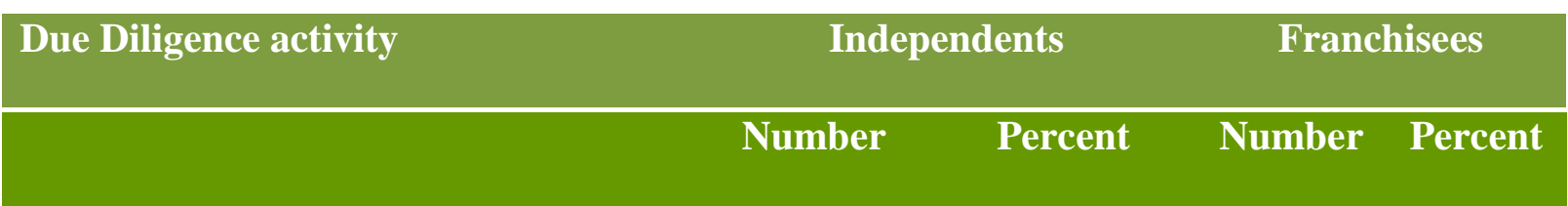

\section{Sought professional advice:}

Consulted an accountant

18

56

15

54

Consulted a lawyer $\dagger$

9

28

18

64

Consulted personal networks

Consulted a friend

8

25

10

36

Consulted family members

6

19

6

21

Conducted own research

$\begin{array}{lcccc}\text { Conducted desktop research } & 16 & 50 & 15 & 54 \\ \text { Conducted market research } \dagger & 13 & 41 & 4 & 14 \\ \text { Spoke to other franchisees } \ddagger & \text { N/A } & \text { N/A } & 16 & 57 \\ \text { Observed the business } & 6 & 19 & 3 & 11 \\ \text { Visited other franchisees } \ddagger & \text { N/A } & \text { N/A } & 6 & 21 \\ \text { Spoke to customers } & 2 & 6 & 2 & 7 \\ \text { type of due diligence } & 10 & 31 & 7 & 25 \\ \text { not conduct any form of due } & 2 & 6 & 0 & 0 \\ \text { nce } & & & & \end{array}$

† Significant differences between independents and franchisees

$\ddagger$ Relevant to franchisees only 
Table 4 Time and cost of Due Diligence (in A\$)

$(n=60)$

\begin{tabular}{lrrrrrr} 
& & & Currently Operating & \multicolumn{2}{c}{ Formerly Operating } \\
\hline Due & Range & Full sample & Independent & Franchisee & Independent & Franchisee \\
Diligence & & & & & \\
Time & $0-76$ & 16.1 & 16.7 & 21.7 & 14.0 & 5.4 \\
(weeks) & & & & & & \\
Cost & $\$ 0-20000$ & $\$ 3214$ & $\$ 2808$ & $\$ 5003$ & $\$ 2422$ & $\$ 1520$ \\
(A\$) & & & & & &
\end{tabular}




\section{Table 5 Overall level of satisfaction}

$(n=60)$

\begin{tabular}{lrrrrr}
$\begin{array}{l}\text { Overall satisfaction level } \\
\text { (Scale: } 1=\text { low, } \mathbf{1 0}=\text { high) }\end{array}$ & & Currently Operating & Formerly Operating \\
& $\begin{array}{r}\text { Total } \\
\text { Sample }\end{array}$ & Independent & Franchisee & Independent & Franchisee \\
\hline $\begin{array}{l}\text { Overall level of satisfaction } \\
\text { with the business }\end{array}$ & 7.5 & 8.2 & 7.9 & 6.3 & 6.4 \\
\hline
\end{tabular}




\section{Table 6 Expectations gap}

$(n=60)$

\begin{tabular}{lrrrrr}
\hline Expectations gap & \multicolumn{2}{c}{ Currently } & Operating & \multicolumn{2}{c|}{ Formerly Operating } \\
\hline & $\begin{array}{r}\text { Total } \\
\text { Sample } \\
\%\end{array}$ & $\begin{array}{r}\text { Independent } \\
\%\end{array}$ & $\begin{array}{r}\text { Franchisee } \\
\%\end{array}$ & $\begin{array}{r}\text { Independent } \\
\%\end{array}$ & $\begin{array}{r}\text { Franchisee } \\
\%\end{array}$ \\
\hline $\begin{array}{l}\text { Lifestyle expectations were } \\
\text { met }\end{array}$ & 70 & 73 & 88 & 60 & 40 \\
$\begin{array}{l}\text { Financial performance } \\
\text { expectations were met }\end{array}$ & 71 & 77 & 82 & 60 & 50 \\
$\begin{array}{l}\text { Relationship expectations were } \\
\text { met }\end{array}$ & 80 & 91 & 82 & 70 & 60
\end{tabular}

